\title{
Özel Eğitim Öğretmenlerinin Özel Eğitime ve Özel Eğitim Öğrencilerine Yönelik Metaforik Algılarının İncelenmesi ${ }^{1}$
}

DOI: $10.26466 /$ opus.754317

\author{
Erkan Efilti *- Beril Demirci ${ }^{* *}$ - Mustafa Karaduman ${ }^{* * *}$ \\ *Doç. Dr, Necmettin Erbakan Üniversitesi Ahmet Keleşoğlu Eğitim Fakültesi, Konya/Türkiye \\ E-Posta: efilti71@gmail.com \\ ORCID: 0000-0003-1158-5764 \\ **Özel Eğitim Öğretmeni, Kayseri/Türkiye \\ E-Posta: $\underline{\text { berildemirci@outlook.com.tr }}$ \\ ORCID: $\underline{0000-0003-4888-0222}$ \\ ***Özel Eğitim Öğretmeni, Karaman/Türkiye
}

E-Posta: karadumanmustafa1996@gmail.com

ORCID: $\underline{0000-0003-1878-0335}$

\begin{abstract}
Öz
Bu çalışmanın amacı özel eğitim öğretmenlerinin özel eğitime ve özel eğitime ihtiyacı olan öğrencilere yönelik metaforik algilarım metafor analizi yoluyla belirlemektir. Araştırma grubu 2019 yılında Konya Il Milli Eğitim Müdürlüğüne bağlı okul ve özel eğitim ve rehabilitasyon alanındaki kurumlarda çalışan 117 öğretmenden oluşmaktadır. Verilerin toplanmasında veri toplama aracı olarak araştırmacılar tarafından geliştirilmiş Özel Ĕ̆itime Yönelik Yapılandırılmış Görüşme formu kullanılmıştır. Araştırmada elde edilen veriler içerik analizi tekniğiyle analiz edilerek yorumlanmıştır. Elde edilen bulgular doğrultusunda özel eğitim öğretmenlerinin özel eğitime ve özel eğitime ihtiyacı olan çocuğa yönelik metaforlar cinsiyetlerine ve meslekteki yıllarına göre farklılaşıp farklılaşmadığı incelenmiştir. Araştırma sonucunda özel eğitim ve özel eğitime ihtiyacı olan çocuğa yönelik pek çok olumlu (eğitim, kitap vb.) ve olumsuz (melek, bebek, yaralı bir kuş vb.) metaforlar ortaya çıkarılmıştır. Oluşturulan metaforlardan özel eğitime yönelik metaforlar özel eği-timi bir ihtiyaç olarak görürken özel eğitime ihtiyacı olan çocuğu da muhtaç bir birey olarak görmekte ve olumsuz tutum oluşturmaktadır. Araştırmada özel eğitim öğretmenlerinin özel eğitimle ilgili farkındalı düzeylerini artırılabilmesi için özel eğitimle ilgili hizmet içi programlar hazırlanması önerilmiştir.
\end{abstract}

Anahtar Kelimeler: Metafor, Metaforik Algı, Özel Ĕ̆itim, Özel Ĕ̆itim Öğretmeni, Özel Eğitime İhtiyact Olan Birey

\footnotetext{
${ }^{1}$ Bu çalışma, 29-31 Ocak 2020 tarihlerinde Kayseri'de düzenlenen 3. Uluslararası Sosyal Bilimleri Kongresi'nde (USBIK 2020) sunulan bildirinin genişletilmiş halidir.
} 


\title{
Investigation Of The Impact Of The Cognitive Behavior Therapy Method On The Theory of Mind Skills Of Mentally Disabled Children
}

\begin{abstract}
The aim of the research, is used to determined the metaphorical perceptions of special education teachers about special education and special educaiton students through metaphor analysis. The research group consists of 117 teachers working in schools and special education and rehabilitation institutions affiliated to Konya Provincial Directorate of National Education in 2019. Data were collected using a Structured Interview for Special Education form developed by the researchers. The data obtained in the study were analyzed and interpreted with content analysis technique. In line with the findings obtained, it has been examined whether the special education teachers' metaphors for the special education and special education students differ according to their gender, years in the profession and the type of school they work. As a result of the research, many positive (education, book etc.) and negative (angel, baby, an injured bird etc.) metaphors were revealed about special education. While metaphors for special education among the created metaphors see special education as a need, they also consider the child who needs special education as a needy individual and create a negative attitude. Studies investigating the causes of these perceptions can be done.
\end{abstract}

Keywords: Metaphor, Metaphoric Perception, Special Education, Special Education Teacher, Special Education Student 


\section{Giriş}

Metaforlar; insanların soyut, karmaşık bir kavramı daha anlaşılır bir hale getirmek için kullandığı zihinsel araçlardır (Saban, Saban, ve Koçbeker, 2006). Saban'a (2008) göre metaforlar, beyindeki zihinsel şemaların birinden diğerine doğru yönelim sağlarlar ve bu sayede bir olguyu başka bir olguyla açılarlar. Kılıç'a (2010) göre metaforlar duygu, düşünce ve olguları daha anlaşılır mesajlara dönüştüren araçlardır. Ek olarak metaforlar; ayrı olan, önemli görülmeyen bilgileri toplayarak anlamlı hale geitrme niteliğine sahiptir.

Metaforlar genel olarak söylemleri güçlü kılmak ve süslemek için kullanılan bir söz sanatı gibi görülse de anlamı ve önemi daha fazlasıdır. Metaforlar genellikle dünyayı algılayışımıza yön veren görme ve düşünme şekli olarak görülmektedir. Metaforlar bireyin kavrama veya olguya bakışını betimleyerek anlatmasıdır (Forceville, 2002). Algısal olarak birbirine benzeyen objelerin birinin diğerine geçen anlam aktarması şeklinde de kabul edilebilirler (Gök ve Erdoğan, 2010). Metafor, bireyin kendini ve yaşadığı dünyayı algılama durumunu içerir (Girmen, 2007). Bireyin belli olan olguyu başka olgu ile zihinsel model şeklinde algılamasıdır (Saban, 2008). Farklı konulardaki çalışmalarda görülmüştür ki metaforlar, düşünme şekli, dik ve bilimin yanında insan hayatının da her bölümünde kendisini ifade etmelerinde de etkisini göstermektedir (Morgan, 1998). Metaforlar bilişsel süreci geliştirerek bireylerde duyuşsal farklılıklar oluşturabilir. Bu süreçlerin etkileşimiyle beraber bireyler metaforları kendi ve başkalarının düşüncelerini aktarırken kullanabilirler.

Günümüze doğru yaklaşırken, metaforların birçok sosyal alandaki etkinliklere nasıl yol gösterdiği, tutum, inanç ve değerleri şekillendirmede belirleyici olduğuna yönelik ilgilerin arttı̆̆ görülmüştür (Çelikten, 2006). Yaşamın her yerinde görülen bu ilgiyi eğitim alnında da görebilmekteyiz. "Metafor" olgusu bireyin özünü anlamasına ve yapılandırmasına yönelik zihinsel haritalama ve modelleme mekanizması şeklinde günümüzdeki eğitimcilerin ilgili odağı olarak onları hayran bırakmaktadır (Saban, 2008).

Metaforlar algıları ortaya koyma noktasında bir veri toplama aracı olarak yıllardan beri kullanılmaktadır (Dikmenli, Çardak ve Yener, 2012). Metaforlar öğretmenlerin ve öğretmen adaylarının algılarını ortaya koymada etkili olarak kullanılmaktadır (Saban, 2004). Görüldüğü gibi eğitim alanında artık çok yaygın olarak kullanılan metafor çalışmaları, son yıllarda öğretmen ye- 
tiştirme programlarının incelenmesi aşamalarında da kullanılmaya başlanmıştır. Metaforik çözümleme yönteminin, öğretmen yetiştirme programlarının temel öğeleri arasındaki dinamik ilişkileri anlama ve düzeltme aşamalarına da katkı sunacağı düşünülmektedir. Eğitim alanında yapılan metafor çalışmalarının, özel eğitime gereksinim duyulmayan okullardaki programlarda öğrenim gören öğrenciler ve öğretmenleri üzerine yoğunlaştığı görülmektedir. Oysa özel eğitime gereksinim duyan öğrencilerin bilişsel, devinişsel, duyuşsal özellikleri engelli olmayan öğrencilerden farklılıklar gösterir. Bu alanda yapılacak metafor çalışmaları ise engelli öğrencilerin algılamaları, zihinsel temsilleri, duygu dünyaları gibi öğrenme sürecinde önemli rol oynayan değişkenlere ışık tutabilir.

Eğitim faaliyetlerinin aktarılmasında baş rolü elinde bulunduran öğretmen, eğitim öğretim faaliyetlerinin hedeflere uygunluğu ve niteliği konusunda da temel sorumluluk sahibi olandır (Mahiroğlu, 2006). Özel eğitime ihtiyacı olan öğrenci sayılarındaki yükseliş (MEB, 2007) bu öğrencilere sağlanacak olan özel eğitim hizmetinin de önemini göstermektedir. Eğitim hizmetlerinde başarının yakalanabilmesinde öğretmen tutumları önemli bir rol oynamaktadır (Erdem, Gezer, ve Çokadar, 2005). Bu bağlamda öğretmenlerin özel eğitim hizmetlerine yönelik algıları önemli bir faktördür (Orel, Zerey, ve Töret, 2004). Özel eğitime ihtiyacı olan bireylere eğitim vermek üzere yetişen özel eğitim öğretmenlerinin özel eğitime ihtiyacı olan bireylere karşı olumlu tutum içinde olmaları, eğitim-öğretim faaliyetlerinin daha nitelikli hale gelmesine ve dolayısıyla özel eğitime ihtiyacı olan bireylerin toplumda bağımsız, üretken bireyler olmalarına olumlu yönde katkılar sağlayacağı düşünülmektedir. Bu nedenle eğitim faaliyetlerinin daha nitelikli ve daha etkili olabilmesi adına özel eğitim öğretmenlerinin özel eğitime yönelik metaforik algıları bu araştırmanın problemini oluşturmaktadır.

Ortaya konan problem doğrultusunda bu araştırmanın amacı özel eğitim öğretmenlerinin "özel eğitim" ve "özel eğitime ihtiyacı olan çocuk" kavramları ile ilgili metaforik algılarının incelenmesidir. Bu amaç doğrultusunda araştırmanın alt amaçları şunlardır:

1. Özel eğitim öğretmenlerinin "özel eğitim" ile ilgili metaforik algıları nelerdir?

a) Özel eğitim öğretmenlerinin "özel eğitim" ile ilgili metaforik alg1ları öğretmenlerin cinsiyetlerine göre farklılaşmakta mıdır? 
b) Özel eğitim öğretmenlerinin "özel eğitim" ile ilgili metaforik alg1ları meslekteki yıllarına göre farklılaşmakta mıdır?

2. Özel eğitim öğretmenlerinin "özel eğitime ihtiyacı olan çocuk" ile ilgili metaforik algiları nelerdir?

a) Özel eğitim öğretmenlerinin "özel eğitime ihtiyacı olan çocuk" ile ilgili metaforik algıları öğretmenlerin cinsiyetlerine göre farklılaşmakta mıdır?

b) Özel eğitim öğretmenlerinin "özel eğitime ihtiyacı olan çocuk" ile ilgili metaforik algıları meslekteki yıllarına göre farklılaşmakta midır?

\section{Yöntem}

\section{Araştırma Modeli}

Bu araştırmada özel eğitim öğretmenlerinin "özel eğitim" ve "özel eğitime ihtiyacı olan birey" kavramlarına yönelik metaforların belirlenmesi amaçlanmıştır. Araştırma fenomenografik yöntem kullanılarak yapılmıştır. Nitel durum çalışması birçok durumu detaylı inceleme konusunda bize yardımcı olur (Creswell, 2013). Olgu bilim araştırması olarak da bilinen fenomenoloji araştırması bireylerin bir fenomenle ilgili yaygın veya ortak algı ve deneyimlerini ortaya koymayı ve incelemeyi temel alan bir yaklaşımdır (Creswell, 2013). Olgu bilim günlük hayatta karşılaşılan ancak üzerinde çok durulmayan olguları araştırmaktadır. Olgularla ilgili kişisel algıların ortaya çıkarılmasında olgu bilim yaklaşımı sıklıkla tercih edilen bir araştırma yöntemidir (Yıldırım ve Şimşek, 2011).

\section{Çalışma Grubu}

Çalışmanın evrenini, 2019 yılında Konya'nın merkez ilçeleri (Selçuklu, Meram, Karatay) içerisinde çalışan özel eğitim öğretmenleri oluşturmaktadır. Örneklem seçimi uygun örneklem seçimi ile belirlenmiştir. Çalışma grubu 117 öğretmenden oluşmaktadır. Uygun örneklem seçim yöntemi, hedeflenen büyüklükteki örneklem grubuna ulaşabilmek amacıyla en yakındaki veya en ulaşılabilir katılımcılardan başlanarak yapılan örneklem seçimidir (Büyüköztürk, Çakmak, Akgün, Karadeniz, ve Demirel, 2013). Çalışma grubundaki öğretmenlerin 78'i kadın 39'u erkektir. Öğretmenler mesleki kıdemlerine göre ise "1-5 yıl”, “6-13 yıl” ve "14-35" yıl şeklinde gruplandırılmıştır. 


\section{Verilerin Toplanması}

Araştırmanın veri toplama aracını araştırmacıların geliştirdiği “Özel Eğitime Yönelik Yapılandırılmış Görüşme Formu" oluşturmaktadır. Görüşme formu hazırlanmadan önce ilgili literatür incelenmiş ve konuyla ilgili yapılan çalışmalardan esinlenerek sorular belirlenmiştir. Daha sonra belirlenen bu sorular alan uzmanlarından oluşan ve benzer araştırmaları olan üç araştırmacıdan görüşler alınmış ve bu görüşler doğrultusunda araştırmada kullanılan sorular oluşturulmuştur. İki kısımdan oluşan Özel Eğitime Yönelik Yapılandırılmış Görüşme Formunun 1. kısmında demografik bilgiler; 2. kısmında özel eğitime ve özel eğitime ihtiyacı olan çocuğa yönelik metaforların ifade edileceği cümleler yer almaktadır.

Formun ikinci kısmında: Özel eğitimi benzetiyorum; çünkü... ifadesiyle katılımcının özel eğitime yönelik metafor algılarını ortaya koymak; Özel eğitime ihtiyacı olan çocuğu ......... benzetiyorum; çünkü... ifadesiyle de katılımcıların özel eğitime ihtiyacı olan çocuğa yönelik metafor algılarının ortaya konulması hedeflenmiştir.

\section{Verilerin Analizi}

Verilerin analizi içerik analizi ile gerçekleştirilmiştir; katılımcıların oluşturduğu metaforlar ve bu metaforlarla ilgili ifadelerden yola çıkılarak kategoriler oluşturulmuştur.

Öğretmenler tarafından oluşturulan metaforların frekans değerleri belirlenmiş ve tablolar halinde sunulmuştur. Oluşturulan metaforlarla ilgili bu kategoriler altında kavramsal kategoriler oluşturulmuş ve metaforlar bu kategoriler altında değerlendirilmiştir. Her bir katılımcının verisi numaraland1rılarak kodlanmıştır.

Oluşturulan metafor cümleleri Saban (2004)'ın da belirttiği şekilde 5 aşamada değerlendirilerek uygun olmayan metafor cümleleri ve metafor olmadığı belirlenen cümleler çıkartılmıştır. Bu aşamalar şu şekildedir:

1. Verilerin okunması ve değerlendirmesi: Toplanan kağıtlar rastgele sıraya konularak rastgele numaralandırılmıştır.

2. Eleme: Metaforlar okunarak değerlendirilmiştir. Metafor niteliği göstermeyen, cevap verilmeyen veya konuyla alakasız olanlar kapsam dışı bırakılmıştır. Kapsam dışına alınanlara örnek olarak: 
- Özel eğitime ihtiyacı olan çocuğu akarsuya benzetiyorum çünkü aktıkça duruluyor (Ö84)

- Özel eğitimi pınara benzetiyorum çünkü sürekli akar (Ö87)

- Özel eğitimi fidan dikmeye benzetiyorum çünkü .... (Ö58)

1. Kategorizasyon: Eleme aşamısını geçen metaforlar ve açıklamalar dikkate alınarak içerik analizi tekniğiyle değerlendirilmiştir. Kategoriler oluşturularak metaforlar belirlenen kategorilere eklenmiştir.

2. Yeniden düzenleme: Burada kategoriler ve metaforlar ilişkisel yönden değerlendirilerek tekrar gözden geçirilmiştir.

3. Geçerlilik ve güvenirlik sağlama: Araştırmada elde edilen metaforlar ve oluşturulan kavramsal kategorilerin doğru adlandırılıp adlandırılmadığı üç uzman tarafından değerlendirilmiş ve görüş ayrıllğı olan kategorilerde yeniden değerlendirilme yapılarak son hali verilmiştir.

\section{Bulgular}

Araştırmanın birinci alt amacı olan " Özel eğitim öğretmenlerinin özel eğitim ile ilgili metaforik algıları" ile ilgili bulgular aşağıda verilmiştir.

Özel eğitim öğretmenlerinin özel eğitime yönelik metaforları ve açıklamaları analiz edilerek Model 1'de sunulmuştur ve yapılan içerik analizine göre 6 kategori elde edilmiştir.

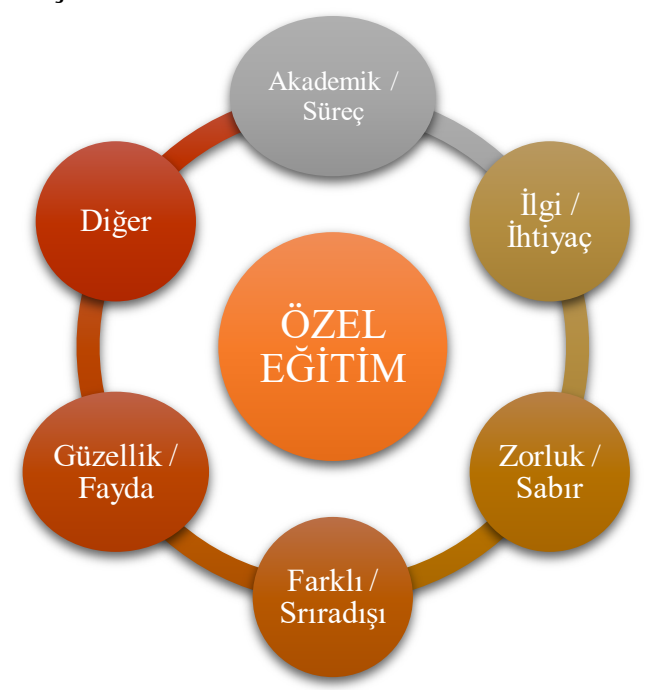

Model 1.Özel Eğitim Öğretmenlerinin Özel Eğitime Yönelik Oluşturduğu Metaforlara İlişkin Kategorileri 


\section{Kategori 1. Akademik / Süreç}

Akademik / Süreç kategorisi eğitim ve zaman alan çalışmalar göz önünde bulundurularak sınıflandırılmıştır. Kategori oluşturulurken metaforlar ve ilgili açılama cümleleri göz önünde bulundurulmuştur. Bu kategori ile ilgili grafik Şekil 1'de verilmiştir:

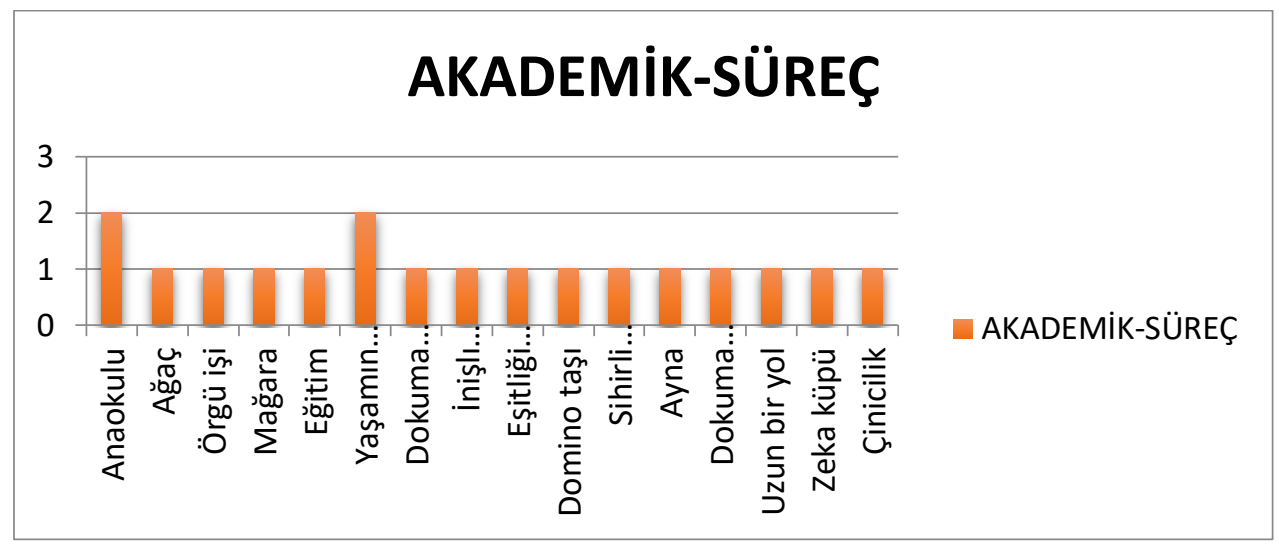

Şekil 1. Akademik / Süreç ile İlgili Grafik

- Özel eğitimi ağaca benzetiyorum çünkü ağactn kökü ne kadar sağlam olursa o kadar sıkı tutunur yaşama. Aynı şekilde öğrencilere ne kadar erken eğitim verilirse o kadar kök salar hayata (Ö38)

- Özel eğitimi yaşamın kendisine benzetiyorum çünkü yaşam gibi bıkmadan ayn eğitimlerin tekrar edilmesidir. (Ö66)

- Özel eğitimi inişli çııışl yola benzetiyorum çünkü eğitime erken başlarsanız yol kat edersiniz, geç başlarsanı zorlanırsını ve zaman ilerledikçe tükenmişlik de artar. (Ö71)

\section{Kategori 2. İlgi / İhtiyaç}

İlgi / İhtiyaç kategorisi bakım isteyen veya gereksinim duyulan anlamlarına gelen kavramlara yönelik metaforlardan oluşturulmuştur. Kategori oluşturulurken metaforlar ve ilgili açıklama cümleleri göz önünde bulundurulmuştur. Bu kategori ile ilgili grafik Şekil 2'de verilmiştir: 


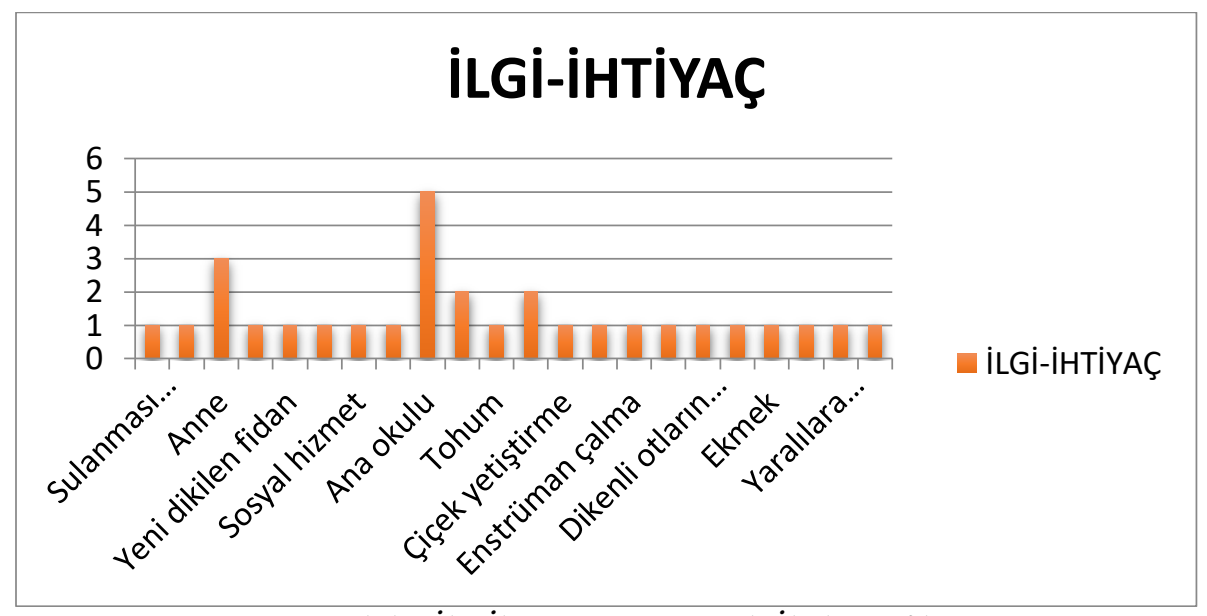

Şekil 2. İlgi İhtiyaç Kategorisi ile İlgili Grafik

- Özel eğitimi sulanması gereken bir bahçeye benzetiyorum çünkü her gün birebir ilgi gerektirir. İlgi üzerlerinden çekildiğ i anda geriye giderler. (Ö2)

- Özel eğitimi anaokuluna benzetiyorum çünkü sürekli sevilmek, ilgilenilmek ve değer görmek istiyorlar. (Ö24)

- Özel eğitimi çiçeğe benzetiyorum çünkü suladıkça yeşerir. (Ö84)

\section{Kategori 3. Zorluk / Sabır}

Zorluk / Sabır kategorisi oluşturulurken özel eğitimin olumsuz yanlarına değindiği yapılması güç iş olarak gördüğü gözlemlenmiştir. Bu kategori ile ilgili grafik Şekil 3'te verilmiştir:

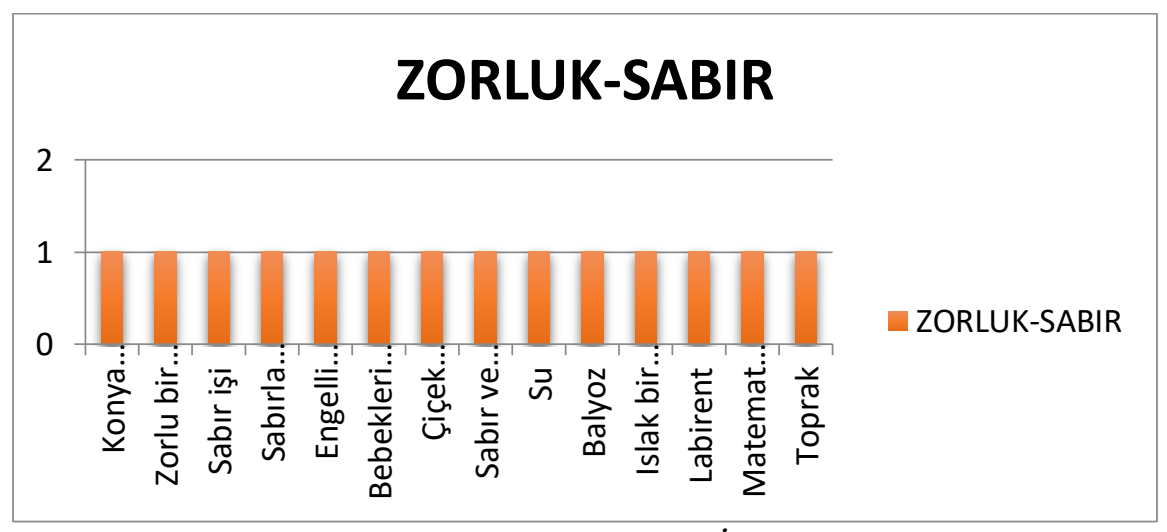

Şekil 3. Zorluk / Sabır ile İlgili Grafik 
- Özel eğitimi Konya Antalya yoluna benzetiyorum çünkü zorlu bir süreç. (Ö11)

- Özel eğitimi sabır işine benzetiyorum çünkü öğretmende sabır olmazsa eğitim olmaz ilerleme kaydedilmez (Ö41)

- Özel eğitimi sabırla gözlenen deneye benzetiyorum çünkü binlerce farkh türde gelişim özellikleri gösteren farkl yetersizlikteki bireylere yapılacak çalışmalar çok iyi analiz ve değerlendirme yapılarak planlama yapılmalı (Ö51)

\section{Kategori 4. Farklı / Sıra dışı}

Farklı / Sıra dışı kategorisi oluşturulurken özel eğitime diğer metaforlara göre daha ütopik seçilen kavramlar ve yorumlar ele alınmıştır. Bu kategori ile ilgili grafik Şekil 4'te verilmiştir:

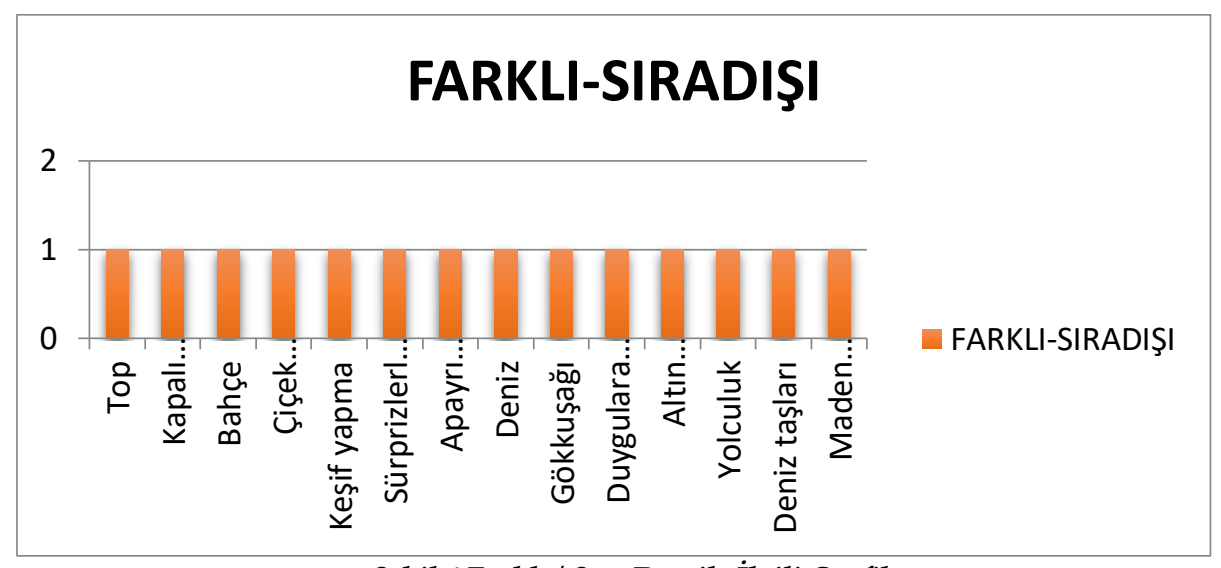

Şekil 4.Farkhı / Sıra Dışı ile İlgili Grafik

- Özel eğitimi duygulara tercüman olmaya benzetiyorum çünkü Özel eğitim çocuklar, insanların hayatı boyunca bizim gözümüzle anlayamıorlar. Onların anlamalarına yardim etmek, tercümanlik mesleği gibi geliyor bana. (Ö80)

- Özel eğitimi bir yolculuğa benzetiyorum çünkü Farklı yolcularn olan uzun bir yola benziyor. Bu yolculukta herkes bir şeyler katıyor. (Ö95)

- Özel eğitimi deniz taşlarma benzetiyorum çünkü her biri dünyada bir deniz kadar uçsuz bucaksız niteliklere sahip ama her biri de o denizin içindeki taşlar kadar birbirinden farkl. (Ö99) 


\section{Kategori 5. Güzellik / Fayda}

Güzellik / Fayda kategorisi belirlenirken özel eğitimin eğlenceli, faydalı yanları dikkat çekmektedir. Bu kategori ile ilgili grafik Şekil 5'te verilmiştir:

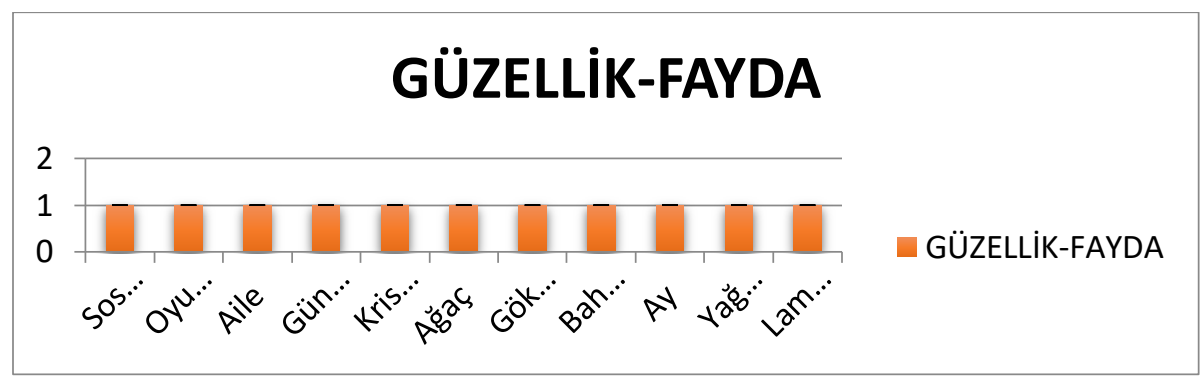

\section{Şekil 5. Güzellik / Fayda Kategorisi ile Illgili Grafik}

- Özel eğitimi oyun alanına benzetiyorum çünkü her şey eğlenceli hale getiriliyor. (Ö32)

- Özel eğitimi aileye benzetiyorum çünkü bir aile ortamının sıcaklı̆̆ı ve paylaşımı var. (Ö43)

- Özel eğitimi güneşe benzetiyorum çünkü çeoresini aydınlatan, ışık saçan, görünmeyen tüm güzellikleri gösteren bir kaynaktır. (Ö61)

\section{Kategori 6. Diğer}

Diğer kategorisi belirlenirken metaforlar arasında herhangi bir ortak yön bulunmayan fakat metafor niteliği taşıyan veriler ele alınmıştır. Bu kategori ile ilgili grafik Şekil 6'da verilmiştir:

\section{DiĞER}

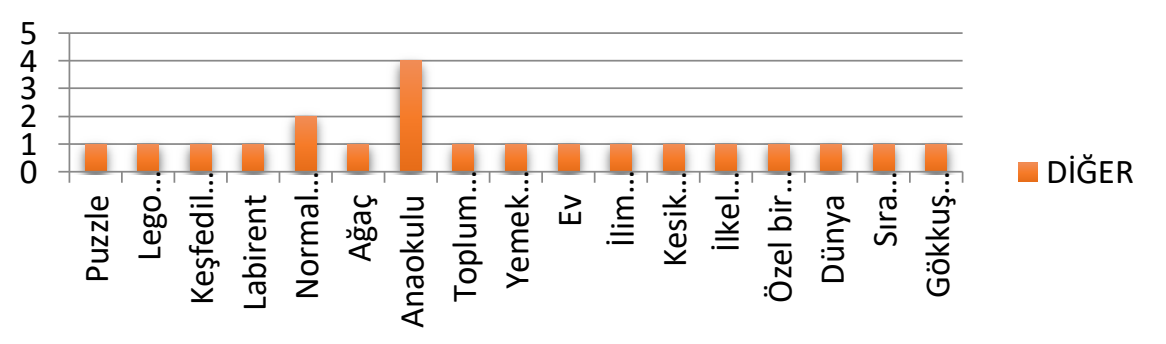

Şekil 6. Diğer Kategorisi ile İlgili Grafik 
- Özel eğitimi normal eğitime benzetiyorum çünkü bu çocukları da birer birey olarak görüyorum. (Ö13)

- Özel eğitimi topluma verilmiş bir emanet olarak görüyorum çünkü beklentisiz, özveri ile çalışılması gereken bir alandır. (Ö31)

- Özel eğitimi dünyaya benzetiyorum çünkü çok geniş bir kapsamı var. (Ö82)

Araştırmanın 1.a alt amacında belirtilen "Özel eğitim öğretmenlerinin özel eğitim ile ilgili metaforik algıları öğretmenlerin cinsiyetlerine göre farklılaşıp farklılaşmadığı" ile ilgili bulgular tablo 1'de verilmiştir.

Tablo 1. Özel Eğitim Öğretmenlerinin Özel Eğitime İlişkin Tespit edilen Metaforlardan Oluşan Kategorilerin Öğretmenlerin Cinsiyetlerine Göre İncelenmesi

\begin{tabular}{lllll}
\hline KATEGORI & \multicolumn{2}{l}{ KADIN } & \multicolumn{2}{l}{ ERKEK } \\
\hline & $\mathrm{f}$ & $\%$ & $\mathrm{f}$ & $\%$ \\
\hline Akademik-süreç & 9 & $12,85 \ldots$ & 9 & $24,32 \ldots$ \\
\hline İlgi-İhtiyaç & 22 & $31,42 \ldots$ & 8 & $21,62 \ldots$ \\
\hline Zorluk-Sabır & 12 & $17,14 \ldots$ & 3 & $8,10 \ldots$ \\
\hline Farklı-Sıra dışı & 8 & $11,42 \ldots$ & 6 & $16,21 \ldots$ \\
\hline Güzellik-Fayda & 4 & $5,71 \ldots$ & 7 & $18,91 \ldots$ \\
\hline Diğer & 15 & $21,42 \ldots$ & 4 & $10,81 \ldots$ \\
\hline Toplam & 70 & 100,00 & 37 & 100,00 \\
\hline
\end{tabular}

Tablo 1 incelendiği zaman; 70 kadın öğretmenin \%12,85'i “Akademik-süreç", \%31,42'si “İlgi-İhtiyaç", \%17,14'ü “Zorluk-Sabır”, \%11,42'si “Farkl1-Sıra dışı", \%5,71'i “Güzellik-Fayda” ve \%21,42'si “Diğer” kategorilerini oluştururken; 37 erkek öğretmenin \%24,32'si “Akademik-süreç", \%21,62'si “İlgi-İhtiyaç", \%8,10'u "Zorluk-Sabır", \%16,21'i “Farkl1-Sıra dışı”, \%18,91'i “GüzellikFayda" ve \%10,81'i “Diğer” kategorilerini oluşturmaktadır.

Araştırmanın 1.b alt amacında belirtilen "Özel eğitim öğretmenlerinin özel eğitim ile ilgili metaforik algıları öğretmenlerin meslekteki yıllarına göre farklılaşıp farklılaşmadığı" ile ilgili bulgular tablo 2' de verilmiştir.

Tablo 2. Özel Eğitim Öğretmenlerinin Özel Eğitime İlişkin Tespit edilen Metaforlardan Oluşan Kategorilerin Öğretmenlerin Cinsiyetlerine Göre İncelenmesi

\begin{tabular}{lllllll}
\hline KATEGORI & $\mathbf{1 - 5}$ YIL & \multicolumn{2}{l}{$\mathbf{6 - 1 3}$ YIL } & \multicolumn{2}{c}{$\mathbf{1 4 - 3 5}$ YIL } \\
\hline & $\mathrm{f}$ & $\%$ & $\mathrm{f}$ & $\%$ & $\mathrm{f}$ & $\%$ \\
\hline Akademik-süreç & 7 & $18,42 \ldots$ & 5 & $12,19 \ldots$ & 6 & $22,22 \ldots$ \\
\hline İlgi-ïhtiyaç & 11 & $28,94 \ldots$ & 12 & $29,26 \ldots$ & 7 & $25,92 \ldots$ \\
\hline Zorluk-Sabır & 4 & $10,52 \ldots$ & 9 & $21,95 \ldots$ & 2 & $7,40 \ldots$ \\
\hline Farklı-Sıra dışı & 9 & $23,68 \ldots$ & 3 & $7,31 \ldots$ & 2 & $7,40 \ldots$ \\
\hline Güzellik-Fayda & 5 & $13,15 \ldots$ & 4 & $9,75 \ldots$ & 1 & $3,70 \ldots$ \\
\hline Diğer & 2 & $5,26 \ldots$ & 8 & $19,51 \ldots$ & 9 & $33,33 \ldots$ \\
\hline Toplam & 38 & 100,00 & 41 & 100,00 & 27 & 100,00 \\
\hline
\end{tabular}


Tablo 2 incelendiği zaman; 1-5 y1l mesleki deneyime sahip olan 38 öğretmenin \%18,42'si "Akademik-süreç", \%28,94'ü "İlgi-İhtiyaç", \%10,52'si "Zorluk-Sabır", \%23,68'i “Farklı-Sıra dışı", \%13,15'i “Güzellik-Fayda” ve \%5,26's1 "Diğer" kategorilerini; 6-13 y1l mesleki deneyime sahip olan 41 öğretmenin \%12,19'u "Akademik-süreç", \%29,26's “İlgi-İhtiyaç", \%21,95'i "Zorluk-Sabır", \%7,31'i “Farklı-Sıra dışı", \%9,75'i “Güzellik-Fayda" ve \%19,51'i “'Diğer" kategorilerini oluştururken; 14-35 yıl mesleki deneyime sahip olan 27 öğretmenin \%22,22'si "Akademik-süreç", \%25,92'si "İlgi-İhtiyaç", \%7,40' 1 "Zorluk-Sabır", \%7,40' 1 “Farkl1-Sıra dışı”, \%3,70'i “Güzellik-Fayda” ve \%33,33'ü "Diğer" kategorilerini oluşturmaktadır.

\section{Özel Ĕ̆itime İhtiyacı Olan Çocuğa Yönelik Metaforlar}

Araştırmanın ikinci alt amacı olan "Özel eğitim öğretmenlerinin özel eğitime ihtiyacı olan çocuk ile ilgili metaforik algıları" ile ilgili bulgular aşağıda verilmiştir.

Özel eğitim öğretmenlerinin özel eğitime yönelik metaforları ve açılamaları analiz edilerek Model 2'de sunulmuştur ve yapılan içerik analizine göre 7 kategori elde edilmiştir.

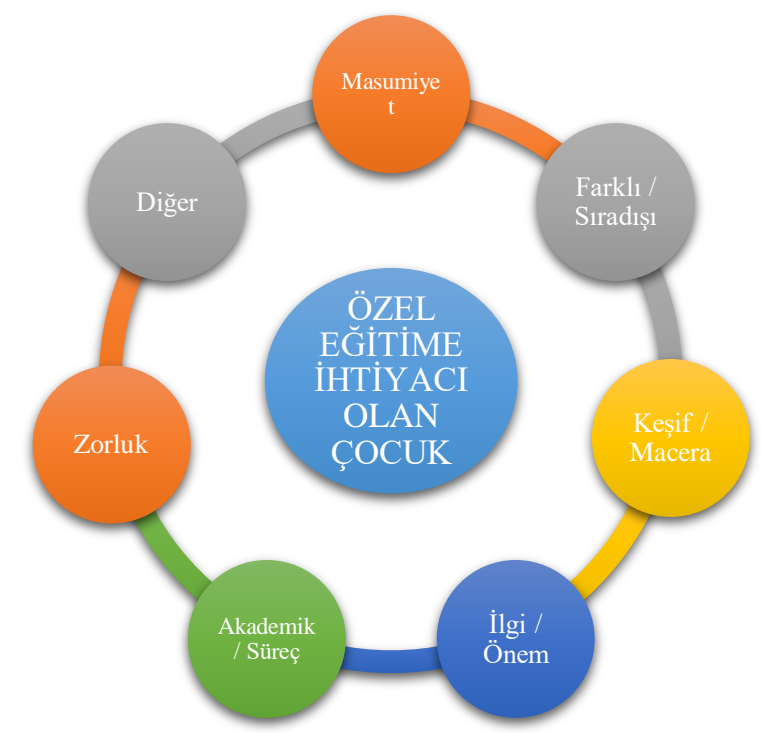

Model 2. Özel Eğitim Öğretmenlerinin Özel Eğitime İhtiyacı Olan Çocuğa Yönelik Metaforlarmin Kategorileri 


\section{Kategori 1. Masumiyet}

Masumiyet kategorisinde "melek" kavramı dikkat çekmektedir. Bu kategori ile ilgili grafik Şekil 7'de verilmiştir:

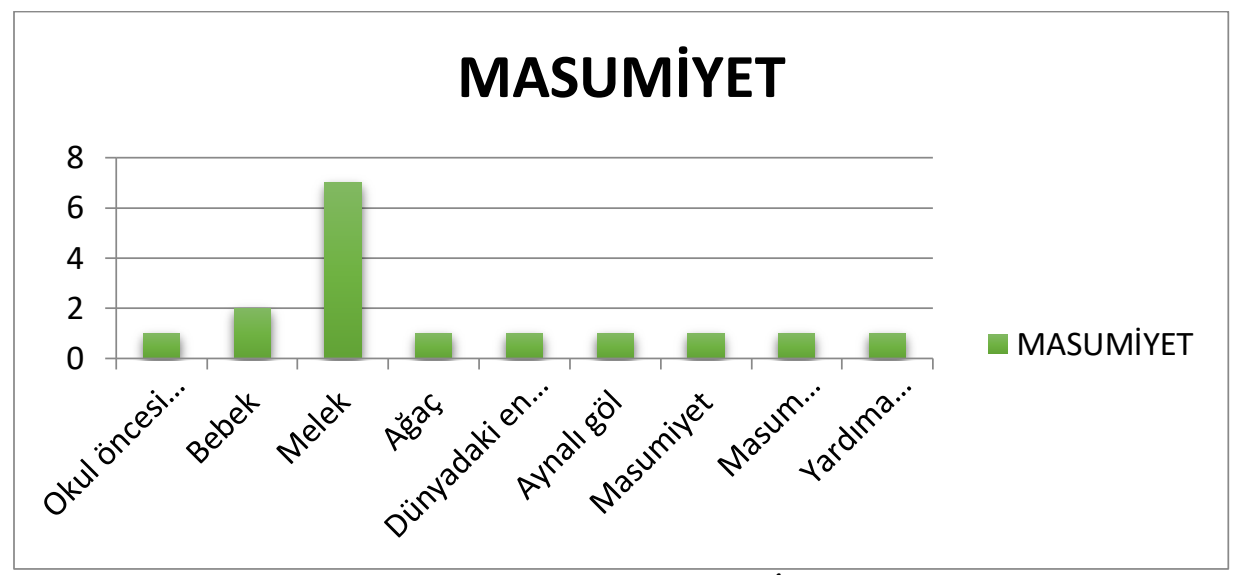

Şekil 7.Masumiyet Kategorisi ile İlgili Grafik

- Özel eğitime ihtiyacı olan çocuğu dünyadaki en şansh varliğa benzetiyorum çünkü karşıllksız sevgiyi bilen, pozitif bireylerdir. Hayatın tüm kötülüklerinden, çkarlarından bihaber olmalar bile şansh olmalar için yeterlidir. (Ö61)

- Özel eğitime ihtiyacı olan çocuğu aynah göle benzetiyorum çünkü Aynah göl o kadar berrak ve temizdir ki çevresinde ne varsa yüreğine yansttır. Sevgi ve ilgi gören çocuk ya da tam tersi özel çocuklar ne görürse onu yansittrlar. (Ö62)

- Özel eğitime ihtiyacı olan çocuğu meleğe benzetiyorum çünkü günahsız, hiçbir şeyden sorumlu olmayan masum çocuklardır. (Ö76)

\section{Kategori 2. Farklı / Stra dişı}

Farklı/ Sıra dışı kategorisi oluşturulurken özel eğitime diğer metaforlara göre daha ütopik seçilen kavramlar ve yorumlar ele alınmıştır. Bu kategori ile ilgili grafik Şekil 8'de verilmiştir: 


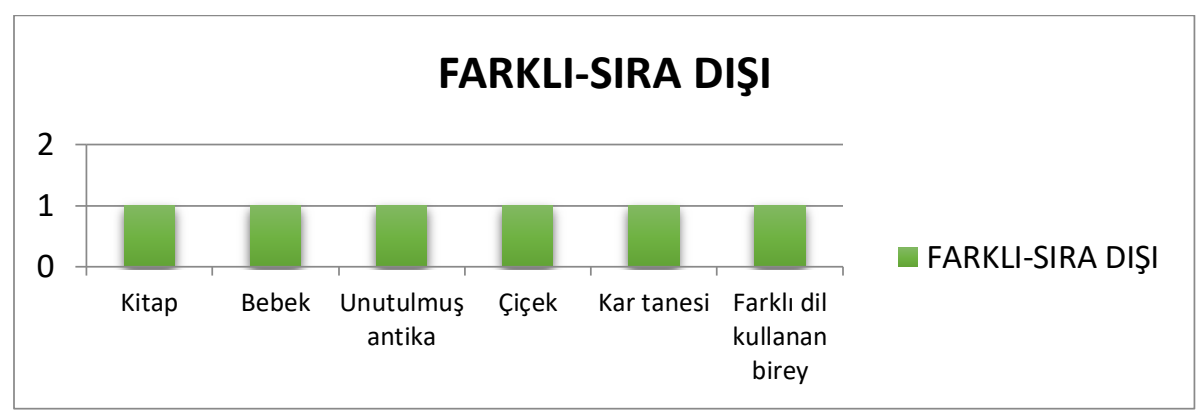

Şekil 8. Farklı / Sıra Dışı Kategorisi ile İlgili Grafik

- Özel eğitime ihtiyacı olan çocuğu kitaba benzetiyorum çünkü her özel öğrenci farkh bir dünyadır. İhtiyaçları ve ilgileri sizi altp farkh dünyalara götürür. (Ö2)

- Özel eğitime ihtiyacı olan çocuğu çiçeğe benzetiyorum bireysel farklilikları onlar doğadaki birbirinden farkl çiçeklere benzetiyor. (49)

- Özel eğitime ihtiyacı olan çocuğu kar tanesine benzetiyorum çünkü hepsi özel çocuklar ve eşleri olmayan taneler. (Ö97)

\section{Kategori 3. Keşif/ Macera}

Keşif / Macera kategorisi oluşturulurken özel eğitime ihtiyacı olan çocuğun gizemli yönlerinden ve farklı bir serüvenin içine girmekten bahsedilmiştir. Bu kategori ile ilgili grafik Şekil 9'da verilmiştir:

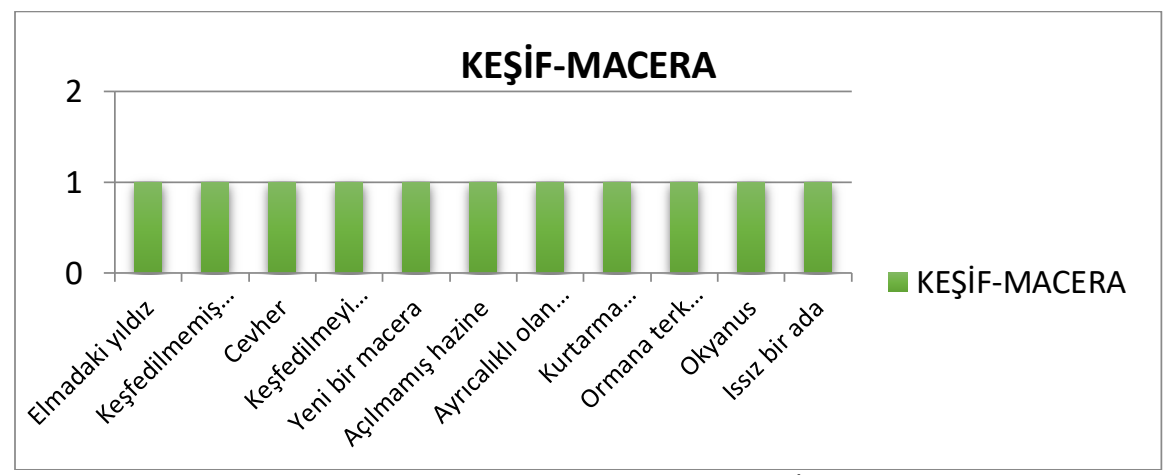

Şekil 9.Keşif / Macera Kategorisi ile İlgili Grafik

- Özel eğitime ihtiyacı olan çocuğu elmadaki yıldıza benzetiyorum nasıl elmanın içindeki yıldız şeklini çok azımız fark edebilmişsek, özel eğitimli çocukların içindeki cevheri de birçoğumuz göremeyiz. (Ö5) 
- Özel eğitime ihtiyacı olan çocuğu cevhere benzetiyorum çünkü çocuktaki cevher keşfedilip su yüzüne çıkarlmall, o yönde geliştirilmeli. (Ö50)

- Özel eğitime ihtiyacı olan çocuğu ormana terk edilmiş̧ çocuğa benzetiyorum çünkü kurda mı çakala mı güveneceğini bilmeden ormanda geziniyor, kurt alırsa besliyor ama kurda denk gelmezse çakallarm elinde oyuncak oluyor. (Ö81)

\section{Kategori 4. İlgi / Önem}

İlgi / Önem kategorisi özel eğitime ihtiyacı olan çocuğu ilgiye ve bakıma ihtiyacı olan varlıklar olarak görmüştür. Özellikle "bebek", "çiçek" ve "fidan" başlıkları dikkat çekmektedir. Bu kategori ile ilgili grafik Şekil 10' da verilmiştir:

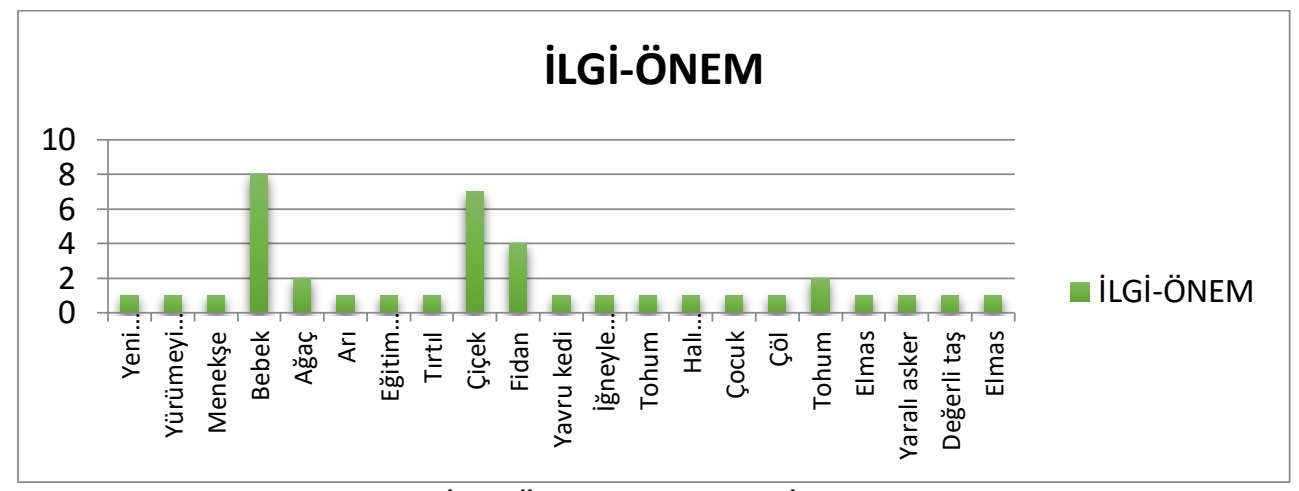

Şekil 10. İlgi / Önem Kategorisi ile İlgili Grafik

- Özel eğitime ihtiyacı olan çocuğu ağaca benzetiyorum çünkü ilgilenirsen meyve verir. (Ö18)

- Özel eğitime ihtiyacı olan çocuğu çiçeğe benzetiyorum çünkü hepsinin yaşamalar için bilgiye ve diğer faaliyetlerle sulanmaya ihtiyaçlar var. (Ö33)

- Özel eğitime ihtiyacı olan çocuğu bebeğe benzetiyorum çünkü bakıma ihtiyacı vardir, sürekli destek ister. (Ö92)

\section{Kategori 5. Akademik / Süreç}

Akademik / Süreç kategorisi eğitim ve zaman alan çalışmalar göz önünde bulundurularak sınıflandırılmıştır. Bu kategori ile ilgili grafik Şekil 11'de verilmiştir: 


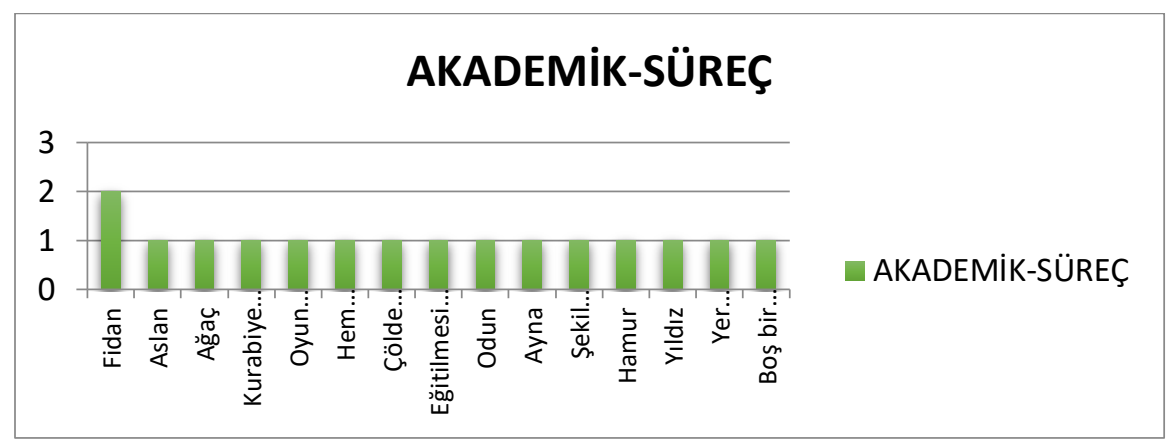

Şekil 11. Akademik / Süreç Kategorisi ile İlgili Grafik

- Özel eğitime ihtiyacı olan çocuğu fidana benzetiyorum çünkü meyve almak için nasll bir süre gerekiyorsa öğrencinin bağımsız bir birey olabilmesi için uzun bir süre gerekiyor. (Ö44)

- Özel eğitime ihtiyacı olan çocuğu oyun hamuruna benzetiyorum çünkü biz oyun hamuruna hangi şekli verirsek o şekle dönüşür. Özel eğitime ihtiyact olan çocuğu da biz şekillendiriyoruz. (Ö70)

- Özel eğitime ihtiyacı olan çocuğu boş bir kasede benzetiyorum çünkü nasıl doldurursanız o şekli alır. (Ö116)

\section{Kategori 6. Zorluk}

Zorluk kategorisi oluşturulurken özel eğitime ihtiyacı olan çocukla ilgilenmemim zor bir iş olduğu vurgulanmıştır. Bu kategori ile ilgili grafik Şekil 12'de verilmiştir:

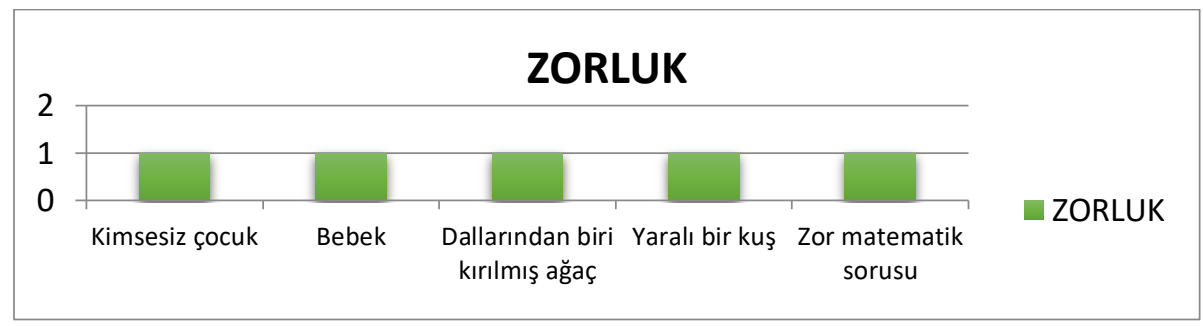

Şekil 12. Zorluk Kategorisi ile İlgili Grafik

- Özel eğitime ihtiyacı olan çocuğu kimsesiz çocuğa benzetiyorum çünkü aileler kopuyor çocuktan ve çocuk hayatın zorluklarıyla tek başına mücadele etmek zorunda kaliyor. (Ö60) 
- Özel eğitime ihtiyacı olan çocuğu yaralı bir kuşa benzetiyorum çünkü destek olmadan, birileri tarafindan ihtiyacı giderilmeden yaşamaya devam edemez, uçamaz diye düşünüyorum. (Ö106)

- Özel eğitime ihtiyacı olan çocuğu zor matematik sorusuna benzetiyorum çünkü herkes çözemez. (Ö109)

\section{Kategori 7. Diğer}

Diğer kategorisi belirlenirken metaforlar arasında herhangi bir ortak yön bulunmayan fakat metafor niteliği taşıyan veriler ele alınmıştır. Bu kategori ile ilgili grafik Şekil 13'te verilmiştir:

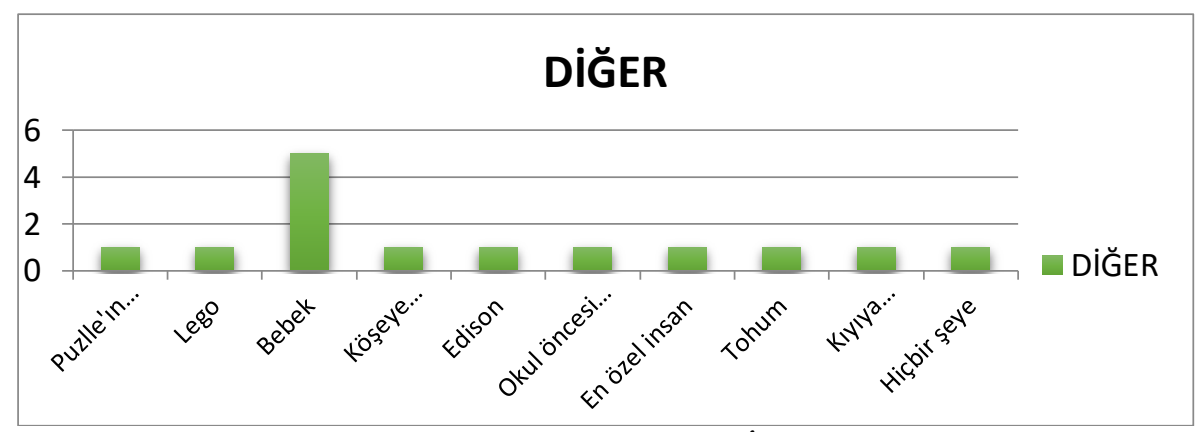

Şekil 13. Diğer Kategorisi ile İlgili Grafik

- Özel eğitime ihtiyacı olan çocuğu bebeğe benzetiyorum çünkü o yaştaki bir çocuğa nasil bakılır ve eğitilir o kadar benzerlik görüyorum. (Ö45)

- Özel eğitime ihtiyacı olan çocuğu tohuma benzetiyorum çünkü filizlenen tohum doğaya, filizlenen çocuk dünyaya renk katar. (Ö93)

- Özel eğitime ihtiyacı olan çocuğu hiçbir şeye benzetiyorum çünkü Özel gereksinimli birey benim için normal bireyden farksızdır. Eğer onu bir şeylere muhtaç veya benzer sayarsanız bir süre sonra tıkanma yaşamanı kaçınlmazdır. Özel eğitim kolektif olarak bir şeylere benzeyebilir ama birey asla bir şeye benzetilmez. Onu nev-i şahsına münhasir görüp ona göre bir planlama yapmak gerekir. (Ö104)

Araştırmanın 2.a alt amacında belirtilen "Özel eğitim öğretmenlerinin özel eğitime ihtiyacı olan çocuğa ile ilgili metaforik algıları öğretmenlerin cinsiyetlerine göre farklılaşıp farklılaşmadığı" ile ilgili bulgular tablo 3'te verilmiştir. 
Tablo 3. Özel Eğitim Öğretmenlerinin Özel Eğitime İhtiyacı Olan Çocuğa İlişkin Tespit edilen Metaforlardan Oluşan Kategorilerin Öğretmenlerin Cinsiyetlerine Göre İncelenmesi

\begin{tabular}{lllll}
\hline KATEGORI & \multicolumn{2}{l}{ KADIN } & \multicolumn{2}{l}{ ERKEK } \\
\hline & $\mathrm{f}$ & $\%$ & $\mathrm{f}$ & $\%$ \\
\hline Masumiyet & 13 & $17,33 \ldots$ & 4 & $11,76 \ldots$ \\
\hline Farklı-Sıra diş1 & 4 & $5,33 \ldots$ & 2 & $5,88 \ldots$ \\
\hline Keşif-Macera & 7 & $9,33 \ldots$ & 4 & $11,76 \ldots$ \\
\hline İlgi-Önem & 26 & $34,66 \ldots$ & 13 & $38,23 \ldots$ \\
\hline Akademik-Süreç & 11 & $14,66 \ldots$ & 5 & $14,70 \ldots$ \\
\hline Zorluk & 4 & $5,33 \ldots$ & 1 & $2,94 \ldots$ \\
\hline Diğer & 10 & $13,33 \ldots$ & 5 & $14,70 \ldots$ \\
\hline Toplam & 75 & 100,00 & 34 & 100,00 \\
\hline
\end{tabular}

Tablo 3 incelendiği zaman; 75 kadın öğretmenin \%17,33'ü "Masumiyet", \%5,33'ü "Farkl1-Sıra dişı", \%9,33'ü "Keşif-Macera", \%34,66's1 "İlgi-Önem", \%14,66's1 "Akademik-Süreç", \%5,33'ü "Zorluk" ve \%13,33'ü “Diğer" kategorilerini oluştururken; 34 erkek öğretmenin \%11,76's “Masumiyet", \%5,88'i "Farkl1-Sıra dışı", \%11,76's1 "Keşif-Macera”, \%38,23'ü "İlgi-Önem”, \%14,70'i "Akademik-Süreç", \%2,94'ü "Zorluk" ve \%14,70'i "Diğer" kategorilerini oluşturmaktadır.

Araştırmanın 2.b alt amacında belirtilen "Özel eğitim öğretmenlerinin özel eğitime ihtiyacı olan çocuk ile ilgili metaforik algıları öğretmenlerin meslekteki yıllarına göre farklılaşıp farklılaşmadığı" ile ilgili bulgular tablo 4'te verilmiştir.

Tablo 4. Özel Eğitim Öğretmenlerinin Özel Eğitime İhtiyacı Olan Çocuğa İlişkin Tespit edilen Metaforlardan Oluşan Kategorilerin Öğretmenlerin Cinsiyetlerine Göre İncelenmesi

\begin{tabular}{|c|c|c|c|c|c|c|}
\hline \multirow[t]{2}{*}{ KATEGORI } & \multicolumn{2}{|c|}{ 1-5 YIL } & \multicolumn{2}{|c|}{ 6-13 YIL } & \multicolumn{2}{|c|}{ 13-35 YIL } \\
\hline & $f$ & $\%$ & $\mathrm{f}$ & $\%$ & $\mathrm{f}$ & $\%$ \\
\hline Masumiyet & 7 & $17,07 \ldots$ & 5 & 12,19 . & 4 & $15,38 \ldots$ \\
\hline Farkl1-Sıra dışı & 5 & $12,19 \ldots$ & 1 & $2,43 \ldots$ & 0 & 0 \\
\hline Keşif-Macera & 4 & $9,75 \ldots$ & 6 & $14,63 \ldots$ & 1 & $3,84 \ldots$ \\
\hline İlgi-Önem & 12 & $29,26 \ldots$ & 15 & $36,58 \ldots$ & 12 & $46,15 \ldots$ \\
\hline Akademik-Süreç & 8 & $19,51 \ldots$ & 5 & 12,19 . & 3 & $11,53 \ldots$ \\
\hline Zorluk & 1 & $2,43 \ldots$ & 4 & $9,75 \ldots$ & 0 & 0 \\
\hline Diğer & 4 & $9,75 \ldots$ & 5 & $12,19 \ldots$ & 6 & $23,07 \ldots$ \\
\hline Toplam & 41 & 100,00 & 41 & 100,00 & 26 & 100,00 \\
\hline
\end{tabular}

Tablo 4 incelendiği zaman; 1-5 yıl mesleki deneyime sahip olan 41 öğretmenin \%17,07'si "Masumiyet", \%12,19'u "Farkl1-Sıra dışı", \%9,75'i “KeşifMacera", \%29,26's1 “ilgi-Önem", \%19,51'i “Akademik-Süreç”, \%2,43'ü “Zorluk" ve \%9,75'i “Diğer" kategorilerini; 6-13 yıl mesleki deneyime sahip olan 
41 öğretmenin \%12,19’u "Masumiyet", \%2,43'ü "Farkl1-Sıra dışı", \%14,63'ü "Keşif-Macera", \%36,58'i “ïlgi-Önem", \%12,19'u "Akademik-Süreç", \%9,75'i "Zorluk" ve \%12,19'u "Diğer" kategorilerini oluştururken; 13-35 y1l mesleki deneyime sahip olan 26 öğretmenin \%15,38'i “Masumiyet”, \%0” 1 "Farkl1-Sıra dışı", \%3,84'ü "Keşif-Macera", \%46,15'i “İlgi-Önem”, \%11,53’ü “AkademikSüreç", \%0” 1 "Zorluk" ve \%23,07'si “Diğer" kategorilerini oluşturmaktadır.

\section{Tartışma}

Katılımcılardan özel eğitimle ilgili elde edilen metaforlar doğrultusunda oluşturulan kategoriler incelendiğinde "İlgi / İhtiyaç" kategorisinin ön plana çıktı̆̆ görülmektedir. Öğretmenlerin özel eğitimi öncelikle, ihtiyaç olarak gördükleri anlaşılmaktadır. Bu kategoriyi oluşturan metaforlar içerisinde anaokulu, anne, çiçek, su gibi temel ihtiyaçlara ve ilgiye vurgu yapan metaforlar görülmektedir. İlgi / ihtiyaç kategorisini oluşturan metaforlar öğretmenlerin özel eğitime yönelik olarak olumlu bir algı yapısına sahip olduklarını göstermektedir. Katılımcıların cinsiyetlerine göre "İlgi / İhtiyaç" kategorisinde özel eğitimle ilgili oluşturulan metaforlara bakıldığında kadın öğretmenlerin oranının daha yoğunluk olduğu görülmektedir. Bunu kadınların çocuklara karşı annelik duygularına sahip olmalarından kaynaklandığı söylenebilir. Başgül (2017) de öğretmen adaylarının özel eğitime yönelik metaforları ile ilgili yapmış olduğu araştırma da, öğretmen adaylarının özel eğitime yönelik metaforları cinsiyet açısından farklılaştı̆̆ı sonucunu bulmuştur. Araştırmacının elde ettiği bu sonuçlar bizim araştırma bulgularımızı da desteklemektedir. “İlgi / İhtiyaç” kategorisini oluşturan metaforlar katılımcıların meslekteki yıllarına göre incelendiğinde belirgin bir fark görülmemiştir. Başgül, 2017 de yapmış olduğu araştırmada, Sınıf öğretmenlerinin özel eğitim ve özel eğitime ihtiyacı olan çocuğa ilişkin metaforları hizmet yılı açısından incelendiğinde 16-20 yıl ve 21 yıl ve üzeri mesleki deneyime sahip olan öğretmenlerin metaforlarının kategori bazında benzer bir dağılım gösterdikleri görülmektedir. Temel (2000) de yapmış olduğu çalışmada okulöncesi öğretmenlerin kaynaştırmaya ilişkin tutumlarında hizmet yılının tutumlara bir etkisi olmadığı sonucuna varmıştır. Literatürde ki bu çalışmaların sonuçları bizim araştırmamızın sonuçlarını desteklemektedir. 
Özel eğitimle ilgili elde edilen metaforlar doğrultusunda oluşturulan "Akademik / Süreç" kategorisi incelendiğinde bu kategoriyi oluşturan anaokulu, yaşamın kendisi, uzun bir yol gibi metaforlardan oluşmaktadır. Burada özel eğitimin belli bir zaman içerisinde gerçekleştiği eğitim ve öğretimi içerisinde barındırmasına vurgu yapıldığı görülmektedir. Katılımcıların cinsiyetlerine göre "Akademik / Süreç" kategorisinde özel eğitimle ilgili oluşturulan metaforlara bakıldığında erkek öğretmenlerin oranının kadın öğretmenlere göre daha yoğun olduğu görülmektedir. "Akademik / Süreç" kategorisini oluşturan metaforlar katılımcıların meslekteki yıllarına göre incelendiğinde belirgin bir fark görülmemiştir.

Özel eğitimle ilgili elde edilen metaforlar doğrultusunda oluşturulan "Zorluk / Sabır" kategorisi incelendiğinde bu kategoriyi oluşturan Konya Antalya yolu, çiçek yetiştirme, matematik sorusu gibi metaforlardan oluşmaktadır. Burada özel eğitimin çeşitli zorluklar içerdiği ve sabır gerektirdiğine vurgu yapıldığı görülmektedir. Katılımcıların cinsiyetlerine göre "Zorluk / Sabır" kategorisinde özel eğitimle ilgili oluşturulan metaforlara bakıldığında kadın öğretmenlerin oranının erkek öğretmenlere göre daha yoğun olduğu görülmektedir. "Zorluk / Sabır" kategorisini oluşturan metaforlar katılımcıların meslekteki yıllarına göre incelendiğinde 6-13 yılları arasında meslekte bulunan öğretmenlerin diğer meslek yılları arasında bulunan öğretmenlere göre daha yoğun olduğu görülmektedir.

Özel eğitimle ilgili elde edilen metaforlar doğrultusunda oluşturulan "Farklı / Sıra dışı" kategorisi incelendiğinde bu kategoriyi oluşturan keşif yapma, deniz taşları, top gibi metaforlardan oluşmaktadır. Burada özel eğitimin farklı bakış açılarına ve sıra dışı tecrübeler yaşatmasına vurgu yapıldığı görülmektedir. Katılımcıların cinsiyetlerine göre "Farklı / Sıra dışı" kategorisinde özel eğitimle ilgili oluşturulan metaforlara bakıldığında cinsiyetlere göre belirgin bir fark olmadığı görülmektedir. "Farklı / Sıra dışı" kategorisini oluşturan metaforlar katılımcıların meslekteki yıllarına göre incelendiğinde 1-5 yılları arasında meslekte bulunan öğretmenlerin diğer meslek yılları arasında bulunan öğretmenlere göre daha yoğun olduğu görülmektedir.

Özel eğitimle ilgili elde edilen metaforlar doğrultusunda oluşturulan "Güzellik / Fayda" kategorisi incelendiğinde bu kategoriyi oluşturan güneş, kristal ve yağmur damlaları gibi metaforlardan oluşmaktadır. Burada özel eğitimin güzelliklerine ve çeşitli faydalarına vurgu yapıldığı görülmektedir. 
Katılımcıların cinsiyetlerine göre “Güzellik / Fayda” kategorisinde özel eğitimle ilgili oluşturulan metaforlara bakıldığında erkek öğretmenlerin oranının kadın öğretmenlere göre daha yoğun olduğu görülmektedir. “Güzellik / Fayda" kategorisini oluşturan metaforlar katılımcıların meslekteki yıllarına göre incelendiğinde 1-5 yılları arasında meslekte bulunan öğretmenlerin Güzellik / Fayda kategorisinde diğerlerine göre daha yoğun olduğu görülmektedir.

Katılımcılardan özel eğitimle ilgili elde edilen metaforlar doğrultusunda oluşturulan diğer kategorisi incelendiğinde, “Diğer" kategorisi belirlenirken metaforlar arasında herhangi bir ortak yön bulunmayan fakat metafor niteliği taşıyan veriler ele alınmıştır. Bu kategoriyi oluşturan metaforlar içerisinde anaokulu, normal eğitim, ilkel yaşam, kesik çizgili yol, sıradağlar gibi birbiriyle bağdaşmayan ve herhangi bir metaforik başlık altına yerleştirilemeyen metaforlar yer almaktadır. Katılımcıların cinsiyetlerine göre "Diğer" kategorisinde özel eğitimle ilgili oluşturulan metaforlara bakıldığında kadın öğretmenlerin çoğunlukta olduğu görülmektedir. "Diğer" kategorisini oluşturan metaforlar katılımcıların meslekteki yıllarına göre incelendiğinde 1-5 yıl arası görev yapmış olan katılımcıların diğer yıllara göre daha azınlıkta olduğu görülmektedir.

Öğretmenlerin özel eğitime dönük metaforları cinsiyet olarak incelendiğinde kategori bazında farklılaştı̆̆ "görülmektedir. Erkek öğretmenlerin metaforları "Akademik / Süreç" ve "Güzellik / Fayda" kategorilerinde yoğunlaşırken, kadın öğretmenlerin metaforları genel olarak "İlgi / İhtiyaç" ve "Zorluk / Sabır" kategorilerinde yoğunlaşmıştır. Mevcut farklılaşmanın erkek öğretmenlerin daha işlevsel ve profesyonel tutumlarından kadınların ise daha duygusal yaklaşım içerisinde olmalarından kaynaklandığı düşünülmektedir. Literatürde özel eğitime ilişkin tutumların cinsiyete göre farklılaştığını ortaya koyan çalışmalar olmakla birlikte cinsiyete göre farklılaşmadığını ileri süren çalışmalar mevcuttur.

Katılımcılardan özel eğitime ihtiyacı olan çocuklar ilgili elde edilen metaforlar doğrultusunda oluşturulan kategoriler incelendiğinde "İlgi / Önem" kategorisinin ön plana çıktı̆̆ı görülmektedir. Daha sonra sırasıyla "Masumiyet", “Diğer", "Akademik / Süreç”, “Keşif / Macera”, "Zorluk”, "Farklı / Sıra dışı" kategorileri altında yoğunlaşmıştır. Öğretmenlerin özel eğitimi öncelikle, "İlgi / Önem" olarak gördükleri anlaşılmaktadır. Bu kategoriyi oluşturan metaforlar içerisinde sırasıyla bebek, çiçek, fidan gibi temel ihtiyaçlara 
ve ilgiye vurgu yapan metaforlar görülmektedir. “İlgi / Önem” kategorisini oluşturan metaforlar öğretmenlerin özel eğitime yönelik olarak olumlu bir alg1 yapısına sahip olduklarını göstermektedir. Katılımcların cinsiyetlerine göre "İlgi / Önem" kategorisinde özel eğitime ihtiyacı olan çocuklarla ilgili oluşturulan metaforlara bakıldığında kadın öğretmenlerin çoğunlukta olduğu görülmektedir. Bu durumun kadınların çocuklara karşı annelik duygularına sahip olmalarından kaynaklandığı söylenebilir. “İlgi / Önem” kategorisini oluşturan metaforlar katılımcıların meslekteki yıllarına göre incelendiğinde meslekteki çalışma aralığı arttıkça bu kategori altındaki metaforların yoğunluğunun da arttı̆̆ görülmektedir.

Özel eğitime ihtiyacı olan çocuklar ilgili elde edilen metaforlar doğrultusunda oluşturulan "Masumiyet" kategorisi incelendiğinde bu kategoriyi oluşturan melek ve bebek gibi metaforlardan oluşmaktadır. Burada özel eğitime ihtiyacı olan çocukların masum varlıklar olduğuna vurgu yapıldığı görülmektedir. Katılımcıların cinsiyetlerine göre "Masumiyet" kategorisinde özel eğitime ihtiyacı olan çocuklarla ilgili oluşturulan metaforlara bakıld1ğında kadın öğretmenlerin çoğunlukta olduğu görülmektedir. Ayrıca bu başlık altındaki melek kavramına ilişkin metaforların her iki cinsiyette de yoğun olarak kullanıldığı görülmektedir. "Masumiyet” kategorisini oluşturan metaforlar katılımcıların meslekteki yıllarına göre incelendiğinde belirgin bir fark görülmemiştir.

Özel eğitime ihtiyacı olan çocuklar ilgili elde edilen metaforlar doğrultusunda oluşturulan "Farklı / Sıra dışı" kategorisi incelendiğinde bu kategoriyi oluşturan kar tanesi, farklı dik kullanan birey gibi metaforlardan oluşmaktadır. Burada özel eğitime ihtiyacı olan çocukların her birinin farklı özellikleri olduğuna vurgu yapıldığı görülmektedir. Katılımclların cinsiyetlerine göre "Farklı / Sıra dışı" kategorisinde özel eğitimle ilgili oluşturulan metaforlara bakıldığında belirgin bir fark olmadığı görülmektedir. "Farklı / Sıra dışı” kategorisini oluşturan metaforlar katılımcıların meslekteki yıllarına göre incelendiğinde belirgin bir fark görülmemiştir.

Özel eğitime ihtiyacı olan çocukla ilgili elde edilen metaforlar doğrultusunda oluşturulan "Keşif / Macera" kategorisi incelendiğinde bu kategoriyi oluşturan açılmamış hazine, yeni bir macera, ıssız bir ada gibi metaforlardan oluşmaktadır. Burada özel eğitime ihtiyacı olan çocukların farklı özelliklerinin keşfedilmesi gerektiğine ilişkin metaforlar yer almaktadır. Katılımcıların 
cinsiyetlerine göre "Keşif / Macera" kategorisinde özel eğitimle ilgili oluşturulan metaforlara bakıldığında belirgin bir fark olmadığı görülmektedir. "Keşif / Macera" kategorisini oluşturan metaforlar katılımcların meslekteki yıllarına göre incelendiğinde belirgin bir fark görülmemiştir.

Özel eğitime ihtiyacı olan çocukla ilgili elde edilen metaforlar doğrultusunda oluşturulan "Akademik / Süreç" kategorisi incelendiğinde bu kategoriyi fidan, şekil almaya hazır hamur, boş bir kaset gibi metaforlardan yer almaktadır. Burada özel eğitime ihtiyacı olan çocuğun eğitilip yetiştirilerek şekil almasına vurgu yapıldığı görülmektedir. Katılımcıların cinsiyetlerine göre "Akademik / Süreç" kategorisinde özel eğitimle ilgili oluşturulan metaforlara bakıldığında belirgin bir fark olmadığı görülmektedir. "Akademik / Süreç" kategorisini oluşturan metaforlar katılımcıların meslekteki yıllarına göre incelendiğinde meslekteki çalışma aralığı arttıkça bu kategori altındaki metaforların yoğunluğunun azaldığı görülmektedir.

Özel eğitime ihtiyacı olan çocuklar ilgili elde edilen metaforlar doğrultusunda oluşturulan "Zorluk" kategorisi incelendiğinde bu kategoriyi oluşturan zor matematik sorusu, kimsesiz çocuk gibi metaforlardan oluşmaktadır. Burada özel eğitime ihtiyacı olan çocukların hem yetişmesi hem de yetiştirilmesi açısından zorluklar barındırdığına vurgu yapıldığı görülmektedir. Katılımcıların cinsiyetlerine göre "Zorluk" kategorisinde özel eğitimle ilgili oluşturulan metaforlara bakıldığında belirgin bir fark olmadığı görülmektedir. "Zorluk" kategorisini oluşturan metaforlar katılımcların meslekteki yıllarına göre incelendiğinde belirgin bir fark görülmemiştir.

Katılımcılardan özel eğitime ihtiyacı olan çocukla ilgili elde edilen metaforlar doğrultusunda oluşturulan "Diğer" kategorisi incelendiğinde, diğer kategorisi belirlenirken metaforlar arasında herhangi bir ortak yön bulunmayan fakat metafor niteliği taşıyan veriler ele alınmıştır. Bu kategoriyi oluşturan metaforlar içerisinde bebek, Edison, hiçbir şey gibi birbiriyle bağdaşmayan ve herhangi bir metaforik başlık altına yerleştirilemeyen metaforlar yer almaktadır. Katılımcların cinsiyetlerine göre “Diğer" kategorisinde özel eğitimle ilgili oluşturulan metaforlara bakıldığında belirgin bir fark olmadığı görülmektedir. "Diğer" kategorisini oluşturan metaforlar katılımcıların meslekteki yıllarına göre incelendiğinde belirgin bir fark görülmemiştir.

Çalışmada "özel eğitim" ve "özel eğitime ihtiyacı olan çocuk" ile ilgili ortaya konulan metaforlar bize öğretmenlerin "özel eğitim" ve "özel eğitime ihtiyacı olan çocuk" ile ilgili kişisel ve eğitimsel deneyimlerle beraber farklılık 
gösterdiği anlaşılmaktadır. Öğretmenlerin “özel eğitim” ve “özel eğitime ihtiyacı olan çocuk" ile ilgili algılarının cinsiyete göre kısmen değiştiği belirlenmiştir. Oluşturulan metaforlar öğretmenlerin özel eğitimle ilgili algılarının özel eğitimin önemi ve kapsamı konusunda yeterli düzeyde yansıtılmadığını ortaya koymaktadır.

\section{Sonuçlar}

$\mathrm{Bu}$ araştırmada "özel eğitim öğretmenlerinin "özel eğitim" ve "özel eğitime ihtiyacı olan çocuk" ile ilgili algıları, metaforlar yoluyla ortaya konulmaya çalişılmıştır. Öğretmenlerin "özel eğitim" ve "özel eğitime ihtiyacı olan çocuk" ile ilgili algıları özel eğitimin özelliği, kapsamı ve işlevi çerçevesi içerisinde incelenmiştir.

Özel eğitime ihtiyacı olan çocukların yoğun olarak engelli olarak düşünüldüğü öğretmenlerin metaforlarından anlaşılmaktadır. Oluşturulan metaforlardan "özel eğitim" için oluşturulan metaforlar özel eğitimi "ihtiyaç" şeklinde algılarken; "özel eğitime ihtiyacı olan çocuk" için oluşturulan metaforlar çocukları muhtaç bir birey olarak görmektedir ve olumsuz bir tutum oluşturmaktadır. Öğretmenlerin "özel eğitim" ve "özel eğitime ihtiyacı olan çocuk" ile ilgili algılarının mesleki tecrübelerine göre fazla değişmediği ortaya konulmuştur. Öğretmenlerin “özel eğitim” ve “özel eğitime ihtiyacı olan çocuk" ile ilgili algılarının okul türüne göre değişiklik göstermediği belirlenmiştir.

\section{Öneriler}

Araştırmanın sonuçlarına bakılarak belirlenen öneriler aşağıda sunulmuştur:

- Özel eğitim öğretmenlerinin "özel eğitim" ve "özel eğitime ihtiyacı olan çocuk" ile ilgili farkındalık düzeylerini artırlabilmesi için özel eğitimle ilgili eğitimler planlanabilir.

- Öğretmenlerin ürettiği metaforlar bu konuda araştırma yapmak isteyen araştırmacılar için kaynak sağlayacaktır.

- Araştırma grubunu özel eğitim öğretmenleri oluşturmaktadır. Farklı branş öğretmenlerinin bulunduğu çalışmalar yapılabilir.

- Yapılan çalışmanın sınırlılıkları değiştirilerek daha geniş kitlelere ulaştırılabilir. 
- Araştırmanın sonucu ile birlikte özel eğitim ve özel eğitime ihtiyacı olan çocuk hakkında bir çok algı saptanmıştır. Bu algılara neden olan çalışmalar üzerinde araştırma yapılabilir. 


\title{
EXTENDED ABSTRACT
}

\section{Investigation Of The Metaphoric Perceptions Of Special Education Teachers For Special Education And Special Education Student}

\author{
Erkan Efilti - Beril Demirci - Mustafa Karaduman \\ Necmettin Erbakan Üniversitesi
}

Metaphors; They are mental tools that people use to make an abstract, complex concept more understandable (Saban, Saban, and Koçbeker, 2006). According to Saban (2008), metaphors provide orientation from one of the mental schemas in the brain to the other and thus explain one phenomenon with another. According to Kılıç (2010), metaphors are tools that transform emotions, thoughts and facts into more understandable messages. Although metaphors are generally seen as a rhetoric used to strengthen and embellish discourses, their meaning and importance are more. Metaphors are generally seen as a way of seeing and thinking that guides our perception of the world. Metaphors are describing the individual's view of the concept or phenomenon (Forceville, 2002).

The rise in the number of students in need of special education (MEB, 2007) shows the importance of the special education service to be provided to these students. Teacher attitudes play an important role in achieving success in educational services (Erdem, Gezer, and Çokadar, 2005). In this context, teachers' perception of special education services is an important factor (Orel, Zerey, \& Töret, 2004). It is thought that the positive attitude of special education teachers who are trained to provide education to individuals in need of special education towards individuals in need of special education will contribute positively to the education-training activities to become more qualified and thus individuals who need special education to become independent and productive individuals in the society. Therefore, the metaphorical perceptions of special education teachers towards special education constitute the problem of this study in order to make educational activities more qualified and more effective. 
In this study, the metaphors of special education teachers regarding the concepts of "special education" and "child in need of special education" are aimed. Research phenomenographic information was examined. Qualitative case study helps us to examine many situations (Creswell, 2013). The universe of the study is the special education teachers working in Konya's central districts (Selçuklu, Meram, Karatay) in 2019. Sample selection transition with sample selection. The working group consists of 117 teachers. 78 of the teachers in the study group are female and 39 of them are male. Teachers are grouped according to their professional seniority as "1-5 years", "6-13 years" and "14-35" years.

The data collection tool of the research is the "Structured Interview Form for Special Education" developed by the researchers. Before preparing the interview form, the relevant literature was examined and the questions were determined, inspired by the studies on the subject. Afterwards, these questions were determined, and the opinions of three researchers who had similar studies were obtained from field experts and the questions used in the study were formed in line with these opinions.

When the categories created in line with the metaphors obtained from the participants about special education are examined, it is seen that the "Interest / Needs" category comes to the fore. It is understood that teachers consider special education primarily as a need. Among the metaphors that make up this category, metaphors that emphasize basic needs and interest such as kindergarten, mother, flower, water are seen. The metaphors that make up the interest / need category show that teachers have a positive perception structure towards special education. Considering the metaphors about special education in the "Interest / Needs" category according to the gender of the participants, it is seen that the ratio of female teachers is more intense. It can be said that this is due to the fact that women have maternal feelings towards children. Başgül (2017) also found in her research on the metaphors of teacher candidates for special education, that the metaphors of teacher candidates for special education differ in terms of gender. These results obtained by the researcher also support our research findings. When the metaphors that make up the "Interest / Need" category were examined according to the years of the participants in their profession, no significant difference was observed. Başgül, in his study in 2017, when the metaphors of classroom teachers about children in need of special education and special education are examined in 
terms of years of service, it is seen that the metaphors of teachers with 16-20 years and 21 years or more of professional experience show a similar distribution on a category basis. Temel (2000) concluded in his study that the service year had no effect on the attitudes of preschool teachers towards inclusion. The results of these studies in the literature support the results of our research.

When the categories created in line with the metaphors obtained from the participants about children in need of special education are examined, it is seen that the "Interest / Importance" category comes to the fore. Later, it focused on "Innocence", "Other", "Academic / Process", "Discovery / Adventure", "Difficulty", "Different / Extraordinary" categories. It is understood that teachers see special education primarily as "Interest / Importance". Among the metaphors that make up this category, metaphors that emphasize basic needs and interest such as baby, flower, and sapling are seen, respectively. The metaphors that make up the "Interest / Importance" category show that teachers have a positive perception structure towards special education. Considering the metaphors about children in need of special education in the "Interest / Importance" category according to the gender of the participants, it is seen that female teachers are in the majority. It can be said that this is due to the fact that women have maternal feelings towards children. When the metaphors that constitute the "Interest / Importance" category are examined according to the years of the participants in the profession, it is seen that the intensity of the metaphors under this category increases as the working range increases.

It is understood from the metaphors of the teachers that children who need special education are considered to be disabled. While the metaphors created for "special education" among the created metaphors perceive special education as "need"; The metaphors created for "child in need of special education" perceive children as a needy individual and create a negative attitude. It has been revealed that teachers' perceptions of "special education" and "child in need of special education" do not change much according to their professional experiences. It has been determined that teachers' perceptions about "special education" and "child in need of special education" do not differ according to the type of school. The metaphors produced by the teachers will provide resources for researchers who want to do research on this subject. The research group consists of special education teachers. Studies with 
different branch teachers can be done. With the result of the research, many perceptions about the child who need special education and special education have been determined. Research can be done on studies that cause these perceptions.

\section{Kaynakça / References}

Arslan, M. M., ve Bayrakçı, M. (2006). Metaforik düşünme ve öğrenme yaklaşımının eğitim öğretim açısından incelenmesi. Milli Eğitim, 35(171), 100-108.

Başgül, M. (2017). Sinfföğretmeni ve sinfföğretmeni adaylarnnn özel eğitime yönelik metaforik alglarnnn incelenmesi. Yüksek lisans tezi. Amasya Üniversitesi Sosyal Bilimler Enstitüsü, Amasya.

Büyüköztürk, Ş., Çakmak, E. K., Akgün, Ö. E., Karadeniz, Ş., ve Demirel, F. (2013). Bilimsel araştırma yöntemleri. Ankara: Pegem Akademi.

Creswell, J. R. (2013). Nitel araştırma yöntemleri: beş yaklaşıma göre nitel araştırma ve araşturma deseni. Ankara: Siyasal Kitabevi.

Çelikten, M. (2006). Kültür veöğretmen metaforları. Administrative science quarterly, 606622.

Dikmenli, M., Çardak, O., ve Yener, D. (2012). Science student teachers' metaphors for scientist. Energy education science and technology, 4(1), 51-66.

Erdem, A. R., Gezer, K., ve Çokadar, H. (2005). Ortaöğretim fen-matematik ve sosyal alanlar öğretmenliği tezsiz yüksek lisans öğrencilerinin öğretmenlik mesleğine ilişkin tutumları. 14. Ulusal Eğitim Bilimleri Kongresi Bildiri Kitabı, içinde (s.471-477). Denizli.

Forceville, C. (2002). The identification of target and source in pictorial metaphors. Journal of pragmatics, 34(1), 1-14.

Girmen, P. (2007). İlköğretim öğrencilerinin konuşma ve yazma sürecinde metaforlardan yararlanma durumları. Yayınlanmamış doktora tezi, Anadolu Üniversitesi, Eskişehir.

Gök, B., ve Erdoğan, T. (2010). Investigation of pre-service teachers' perceptions about concept of technology through metaphor analysis. The Turkish online journal of educational technology, 9(2), 145-160.

Mahiroğlu, A. (2006). Öğretmenlik mesleği ve öğretmen yetiştirmede gelişmeler ve yenilikler. Ö. Demirel, veZ. Kaya, Eğitim bilimine giriş içinde. İstanbul: Pegem Yayincilik.

MEB. (2007). Milli Eğitim istatistikleri örgün eğitim 2006-2007. 02 27, 2020 tarihinde http://sgb.meb.gov.tr/istatistik/meb_istatistikleri_orgun_egitim_2006_2007.pdf adresinden alındı 
Özel Eğitim Öğretmenlerinin Özel Eğitime ve Özel Eğitim Öğrencilerine Yönelik Metaforik Algilarinin İncelenmesi

Morgan, G. (1998). Yönetim ve örgüt teorilerinde metafor. (G. Bulut, Çev.) İstanbul: BZD Yayincilik.

Orel, A., Zerey, Z., ve Töret, G. (2004). Sinıf öğretmeni adaylarınn kaynaştrmaya yönelik tutumlarınn incelenmesi. Ankara üniversitesi eğitim bilimleri fakültesi özel eğitim dergisi, 5(1), 23-33.

Saban, A. (2004). Giriş düzeyindeki sınıf öğretmeni adaylarının "öğretmen" kavramına ilişkin ileri sürdükleri metaforlar. Türk eğitim bilimleri dergisi, 2(2), 131-155.

Saban, A. (2008). Öğretmen adaylarının "öğrenci" kavramına ilişkin sahip oldukları zihinsel imgeler. Türk eğitim bilimleri dergisi, 7(2), 281-326.

Saban, A., Saban, A., ve Koçbeker, B. N. (2006). Examining of teacher candidates' perceptions towards "teacher" concept through metaphor analysis. Educational sciences: theory and practice journal, 6(2), 461-522.

\section{Kaynakça Bilgisi / Citation Information}

Efilti, E., Demirci, B., ve Karaduman, M. (2021). Özel eğitim öğretmenlerinin özel eğitime ve özel eğitim öğrencilerine yönelik metaforik algılarının incelenmesi. OPUS-Uluslararası Toplum Araştırmaları Dergisi, 17(33), 221-251. DOI: 10.26466/opus.754317 